\title{
COMPARATIVE ANALYSIS OF SHELL OCCUPATION BY TWO SOUTHERN POPULATIONS OF THE HERMIT CRAB Loxopagurus loxochelis (DECAPODA, DIOGENIDAE)
}

\author{
Luciane Ayres-Peres ${ }^{1}$, Aline Ferreira Quadros ${ }^{2}$ and Fernando L. Mantelatto ${ }^{3 *}$ \\ ${ }^{1}$ Universidade Federal do Rio Grande do Sul \\ Departamento de Zoologia, Laboratório de Carcinologia, Instituto de Biociências \\ (Bento Gonçalves, 9500, prédio 43435, 91501-970 Porto Alegre, RS, Brasil) \\ ${ }^{2}$ Universidade Federal da Integração Latino-Americana (UNILA) \\ Parque Tecnológico da Itaipu (PTI) \\ (Av. Tancredo Neves, 6731; Caixa Postal 2044, 85856-970 Foz do Iguaçú, PR, Brasil) \\ ${ }^{3}$ Universidade de São Paulo \\ Faculdade de Filosofia, Ciências e Letras de Ribeirão Preto (FFCLRP) - Departamento de Biologia, Laboratório \\ de Bioecologia e Sistemática de Crustáceos
}

(Av. Bandeirantes, 3900; 14040-901 Ribeirão Preto, SP, Brasil)

*Corresponding author: flmantel@usp.br

\begin{abstract}
A B S T R A C T
The present study aimed to comparatively verify the relation between the hermit crabs and the shells they use in two populations of Loxopagurus loxochelis. Samples were collected monthly from July 2002 to June 2003, at Caraguatatuba and Ubatuba Bay, São Paulo, Brazil. The animals sampled had their sex identified, were weighed and measured; their shells were identified, measured and weighed, and their internal volume determined. To relate the hermit crab's characteristics and the shells' variables, principal component analysis (PCA) and a regression tree were used. According to the PCA analysis, the three gastropod shells most frequently used by L. loxochelis varied in size. The regression tree successfully explained the relationship between the hermit crab's characteristics and the internal volume of the inhabited shell. It can be inferred that the relationship between the morphometry of an individual hermit crab and its shell is not straightforward and it is impossible to explain only on the basis of direct correlations between the body's and the shell's attributes. Several factors (such as the morphometry and the availability of the shell, environmental conditions and inter- and intraspecific competition) interact and seem to be taken into consideration by the hermit crabs when they choose a shell, resulting in the diversified pattern of shell occupancy shown here and elsewhere.
\end{abstract}

\section{RESUMO}

O presente estudo teve como objetivo verificar de forma comparativa a relação entre ermitões e conchas utilizadas por duas populações de Loxopagurus loxochelis. Foram realizadas coletas mensais, de julho 2002 a junho 2003, nas Enseadas de Caraguatatuba e de Ubatuba, São Paulo, Brasil. Os animais amostrados foram identificados quanto ao sexo, pesados, e mensurados; as conchas de gastrópodes foram identificadas, mensuradas, pesadas e tiveram seu volume interno determinado. Para relacionar as variáveis dos ermitões com as conchas foram utilizadas a análise de componentes principais (PCA) e a árvore de regressão. As três conchas de gastrópodes utilizadas mais intensamente diferiram em tamanho de acordo com a PCA. A árvore de regressão explicou com sucesso a relação entre características do ermitão e volume interno das conchas habitadas. Inferiu-se que a relação entre a morfometria de um ermitão e sua concha não é simples e não é possível de ser explicada com base somente em correlações diretas entre atributos do corpo e da concha. Inúmeros fatores (como morfometria e disponibilidade da concha, condições ambientais e competição inter e intra-específica) interagem e devem ser levados em consideração na escolha de uma concha pelos ermitões, resultando no diversificado padrão de ocupação de conchas demonstrado neste e em outros trabalhos correlatos.

Descriptors: Diogenidae, Shell utilization, PCA, Regression tree, Atlantic.

Descritores: Diogenidae, Utilização de conchas, PCA, Árvore de regressão, Atlântico. 


\section{INTRODUCTION}

Gastropod shells constitute a vital resource for hermit crabs (CONOVER, 1978; GARCIA; MANTELATTO, 2000), providing them with many important conditions, such as protection against predators (REESE, 1969; VANCE, 1972; BERTNESS, 1982) and physical stress (BOLLAY, 1964; REESE, 1969), and granting protection to their eggs during the egg-laying period (FOTHERINGHAM, 1976). Gastropod shell availability acts as a limiting factor to these animals' populations (PROVENZANO, 1960; VANCE, 1972a; KELLOGG, 1976; SPIGHT, 1977; BARNES, 1999) and influences their growth rates (MARKHAM, 1968; CHILDRESS, 1972; VANCE, 1972 ; FOTHERINGHAM, 1976a; BERTNESS, 1981; HAZLETT, 1981) and egg production (BOLLAY, 1964; BERTNESS, 1981; ELWOOD et al., 1995; MANTELATTO et al., 2002).

Understanding the hermit crab's pattern of shell occupancy is not a straightforward task. Its selection of its shell takes into consideration mainly the latter's size and shape (GRANT; ULMER, 1974), but also involves specific exploratory behavior by which the shell's overall condition, weight, color and even internal volume can be assessed (MITCHELL, 1976). Moreover, the pattern of the hermit crab's shell occupancy may vary amongst populations of a given species as it is influenced both by the availability of a particular kind of shell and the environmental characteristics (MANTELATTO; GARCIA, 2000), as well as by the relative abundance of the living gastropods and their mortality rates (OHMORI et al., 1995; MANTELATTO; MEIRELES; 2004). All these factors are closely related to the biogeographical distribution of the species and the adjacent environmental conditions in those different areas (MANTELATTO et al., 2010).

Hermit crabs tend to occupy shells in better condition when inhabiting places with high shell abundance, as distinct from places with a shortage of shells (SCULLY, 1979). There is often a large overlap in the way the shells are used by coexistent species (HAZLETT, 1981). The change to a new shell may occur when the hermit crab finds an empty one or obtains it from another individual, through a ritualized behavior (HAZLETT, 1981; SATO; SENO, 2006).

The hermit crab Loxopagurus loxochelis (Moreira, 1901) (Diogenidae) is a monotypical hermit crab genus, endemic to the southwestern Atlantic coast, occurring in Brazil (from Bahia to Rio Grande do Sul), Uruguay, and Argentina (MELO, 1999). As a consequence of its widespread distribution in South America, knowledge of its biology has been accumulating over recent years (see AYRES-PERES;
MANTELATTO, 2008 for revision). Recollecting specific information related to shell studies in that area, we may cite the epibiont diversity and the pattern of shell occupancy (MARTINELLI; MANTELATTO, 1998 and 1999; AYRES-PERES et al., 2008; CARRANZA et al., 2008; AYRES-PERES; MANTELATTO, 2010), shell preference under laboratory conditions (BIAGI et al., 2006) and the shell's influence on fecundity (TORATI; MANTELATTO, 2008)

In the light of this scenario, this study sought to ascertain the comparative relationship between the hermit crabs and the shells they use, in two populations of L. loxochelis. This investigation was based on biological data obtained by continuous sampling undertaken in natural environment and compared by means of multivariate analysis.

\section{Material and Methods}

$$
\text { Sampling }
$$

Loxopagurus loxochelis was sampled monthly from July 2002 to June 2003 , in two areas: Caraguatatuba $\left(23^{\circ} 36^{\prime} 09^{\prime \prime}\right.$ to $23^{\circ} 40^{\prime} 12^{\prime \prime S}$ and $45^{\circ} 07^{\prime} 16^{\prime \prime}$ to $\left.45^{\circ} 25^{\prime} 35^{\prime \prime} \mathrm{W}\right)$ and Ubatuba $\left(23^{\circ} 26^{\prime} 08^{\prime \prime}\right.$ to $23^{\circ} 31^{\prime} 57^{\prime \prime S}$ and $44^{\circ} 55^{\prime} 28^{\prime \prime}$ to $45^{\circ} 03^{\prime} 18^{\prime \prime} \mathrm{W}$ ), in São Paulo State, Brazil. A boat equipped with two "double-rig" trawl nets was used to sample the hermit crabs at 5, 10, 15, 20, 25 and $30 \mathrm{~m}$ deep along a transect parallel to the coastline (AYRES-PERES; MANTELATTO, 2008a). After being captured, the crabs were kept frozen until further analysis in the laboratory. After defreezing, at room temperature, the crabs were removed manually from their shells. Then their characteristics were recorded as follows: sex (according to the gonopore position), fresh weight (in $\mathrm{g}$ ), cephalothoracic shield length (CSL) and width (CSW), and left chelae length (LCL) and width (LCW). Individuals with CSL $<4.0 \mathrm{~mm}$ were considered juveniles, following Ayres-Peres and Mantelatto (2008, 2008a). Gastropod shells were identified according to Rios (1994), and the following characteristics of each shell were analyzed: aperture length (SAL) and width (SAW), dry weight (SDW) and internal volume (SIV). The shells' internal volume was obtained by filling them with sand $(\varnothing=0.105-$ $0.25 \mathrm{~mm}$ ), as in Bertness (1981) and Mantelatto and Garcia (2000). The shells broken during the crabs' removal were discarded for the purposes of this analysis.

\section{Statistical Analysis}

1) Shell occupation in relation to areas/depths: cluster analysis using the PVCLUST package (SUZUKI; SHIMODAIRA, 2006), available for R software (R 
Core Development Team, 2010), was applied to verify whether the gastropod shells utilized by L. loxochelis differed across different water depths $(5,10,15,20,25$ and $30 \mathrm{~m}$ ) and sampling areas (Caraguatatuba and Ubatuba regions).

2) Hermit crab and gastropod shell characteristics: the three shells that were most used by $L$. loxochelis in our samples: Buccinanops gradatum, Olivancillaria urceus and Stramonita haemastoma - and which corresponded to about $90 \%$ of the total individuals captured (see Results) - were chosen to relate the hermit crab's characteristics to the pattern of shell occupancy. These chracteristics (width, length, internal volume and dry weight) were compared using principal component analysis (PCA). PCA was also employed to compare the hermit crab's characteristics (cephalothoracic shield length and width, chelipeds length and width, weight) as between the two study areas. The significance of the differences between these groups was tested using Analysis of Similarity (ANOSIM). A third PCA was employed to see whether the males and females of $L$. loxochelis occupied different gastropod shells according to their attributes. We employed a 2-way ANOSIM to test the differences between sexes and species. In both ANOSIM tests, the Euclidean dissimilarity measure and 10000 permutations were used. PCA and ANOSIM were run using PAST software (HAMMER et al., 2001).

3) Hermit crab versus shell: An attempt was made to relate the hermit crab's characteristics (sex, dry weight, cephalothoracic shield length and width, propodus length and width) as independent variables influencing the use of the shell through a regression tree analysis. Regression trees are particularly useful in ecological studies for at least two reasons: this method permits the joint use of both qualitative and quantitative variables as predictors (independent variables) and it allows the inclusion of multiple predictors irrespective of whether multicolinearity exists between them (DEATH; FABRICIUS, 2000; PRASAD et al., 2006). regression trees are, therefore, well suited to relate the hermit crab's characteristics to the shell's, because the former often include both qualitative (e.g., sex) and quantitative variables (e.g., size, weight); further, variables such as size, volume and weight are often closely correlated to each other, i.e., are collinear. Four trees were built, one for each shell's characteristics (aperture width, length, dry weight and internal volume) as the dependent variable; however, only the tree that explained a significant portion of the total variance was kept. This tree was then pruned (using the 1-SE rule; see DE'ATH, 2002) to obtain a tree with a minimum number of splits but that explained the largest portion of the variance. These procedures used the RPART package
(THERNEAU; ATKINSON, 2010) for R software (R Core Development Team, 2010).

\section{RESULTS}

In Caraguatatuba, 366 hermit crabs using 14 different kinds of gastropod shells were captured. Of this total, $53.8 \%$ of the individuals occupied the Buccinanops gradatum shells, $31.3 \%$ occupied the Olivancillaria urceus and $8.5 \%$ occupied the Stramonita haemastoma. In Ubatuba, L. loxochelis was less abundant (126 ind.) and found only in five gastropod species' shells. Sixty-three percent of these individuals were found in $O$. urceus and $30.2 \%$ in $B$. gradatum (Table 1 ).

The cluster analysis indicated that the gastropod community inhabited by $L$. loxochelis in the two bays was different; it also evidenced differences between depths. Loxopagurus loxochelis was absent at $5 \mathrm{~m}$ deep, in Ubatuba. At the shallowest site (5m deep) of Caraguatatuba and at the deepest sites of Caraguatatuba and Ubatuba bays (30 and $25 \mathrm{~m}$, respectively), $L$. loxochelis used a different combination of shells from that used at intermediate depths (Fig. 1). In the shallow waters of Caraguatatuba $(5 \mathrm{~m})$, L. loxochelis was found to occupy the greatest diversity of shells, comprising eight gastropod species' (Buccinanops gradatum, Chicoreus tenuivaricosus, Dorsanum molinifera, Fusinus brasiliensis, Olivancillaria urceus, Phalium granulata, Polinices hepaticus and Stramonita haemastoma), though it was most frequently found in S. haemastoma. On the other hand, at $30 \mathrm{~m}$ in this same bay, the hermit crabs were distributed among four gastropod species' shells. The cluster formed in the intermediate depths of Caraguatatuba (Fig. 1) is characterized by the use of five or six species, but highly skewed towards $B$. gradatum (60\% of total individuals, on average), followed by $O$. urceus $(27 \%$ of total individuals, on average). The intermediate depths at Ubatuba were quite different from that cluster (Fig. 1), as fewer gastropod species were used (two to five) and the shell occupation was more evenly distributed among $B$. gradatum and $O$. urceus. The deepest site cluster at Ubatuba $(25 \mathrm{~m})$ differed from the others mainly because the shell used by $L$. loxochelis was highly skewed towards $O$. urceus (22 out of 23 individuals).

The three gastropod shells most frequently used by L. loxochelis varied in size (Fig. 2). PCA axis 2 (23\% of variance explained) indicates that $O$. urceus shells are heavier than those of $S$. haemastoma and $B$. gradatum, which have, on the other hand, larger aperture widths (Fig. 2). There were little differences between the species along the PCA axis 1, which was related to the shell's internal volume and aperture length (Fig. 2). ANOSIM indicated that the differences 
between the species are significant (ANOSIM $\mathrm{r}=$ 0.18; $\mathrm{p}<$ 0.0001): $O$. urceus differing from $S$. haemastoma (Bonferroni-corrected $\mathrm{p}=0.013$ ) and from $B$. gradatum (Bonferroni-corrected $\mathrm{p}<0.0001$ ).

The individuals of the two $L$. loxochelis populations studied did not differ with respect to the body characteristics measured (ANOSIM $r=0.002 ; p$ $=0.45)$ (Fig. 3). Despite their being different populations the geographical separation and the environmental pressures were insufficient to produce morphometric changes whether in the males or the females of the population studied.

Table 1. Gastropod species occupied by Loxopagurus loxochelis (Anomura, Diogenidae) in Caraguatatuba (CAR) and Ubatuba (UBA) bays, São Paulo State, Brazil, from July/2002 to June/2003.

\begin{tabular}{|c|c|c|c|c|c|c|}
\hline \multirow{2}{*}{ Gastropod shells } & \multicolumn{2}{|c|}{ Males } & \multicolumn{2}{|c|}{ Non-ovigerous females } & \multicolumn{2}{|c|}{ Ovigerous females } \\
\hline & CAR & UBA & CAR & UBA & CAR & UBA \\
\hline $\begin{array}{l}\text { Agaronia travassoi } \\
\text { (Morretes, 1938) }\end{array}$ & - & 01 & - & - & - & - \\
\hline $\begin{array}{l}\text { Buccinanops deformis } \\
\text { (King \& Broderip, 1832) }\end{array}$ & 01 & - & - & - & 02 & - \\
\hline $\begin{array}{l}\text { Buccinanops gradatum } \\
\text { (Deshayes, 1844) }\end{array}$ & 120 & 20 & 60 & 15 & 16 & 03 \\
\hline $\begin{array}{l}\text { Chicoreus tenuivaricosus } \\
\text { (Dautzenberg, 1927) }\end{array}$ & - & - & 01 & - & - & - \\
\hline $\begin{array}{l}\text { Conus clerii } \\
\text { Reeve } 1844\end{array}$ & - & - & 01 & - & - & - \\
\hline $\begin{array}{l}\text { Cymatium parthenopeum } \\
\text { (von Salis, 1793) }\end{array}$ & 01 & 1 & 01 & - & - & - \\
\hline $\begin{array}{l}\text { Dorsanum moliniferum } \\
\text { (Valenciennes, 1834) }\end{array}$ & 01 & - & 01 & - & - & - \\
\hline $\begin{array}{l}\text { Fusinus brasiliensis } \\
\text { (Grabau, 1904) }\end{array}$ & 02 & - & 01 & - & - & - \\
\hline $\begin{array}{l}\text { Olivancillaria urceus } \\
\text { (Röding, 1798) }\end{array}$ & 66 & 56 & 40 & 22 & 08 & 02 \\
\hline $\begin{array}{l}\text { Phalium granulata } \\
\text { (Born, 1778) }\end{array}$ & 03 & - & - & - & - & - \\
\hline $\begin{array}{l}\text { Polinices hepaticus } \\
\text { (Röding, 1798) }\end{array}$ & 03 & - & - & - & 02 & - \\
\hline $\begin{array}{l}\text { Polinices lacteus } \\
\text { (Guilding, 1834) }\end{array}$ & - & - & 01 & - & - & - \\
\hline $\begin{array}{l}\text { Prunum martini } \\
\text { (Petit, 1853) }\end{array}$ & - & - & 01 & - & - & - \\
\hline $\begin{array}{l}\text { Stramonita haemastoma } \\
\text { (Linnaues, 1767) }\end{array}$ & 23 & 3 & 06 & 1 & 02 & 02 \\
\hline $\begin{array}{l}\text { Tonna galea } \\
\text { (Linnaeus, 1758) }\end{array}$ & 01 & - & - & - & - & - \\
\hline Total & 221 & 81 & 113 & 38 & 30 & 07 \\
\hline
\end{tabular}




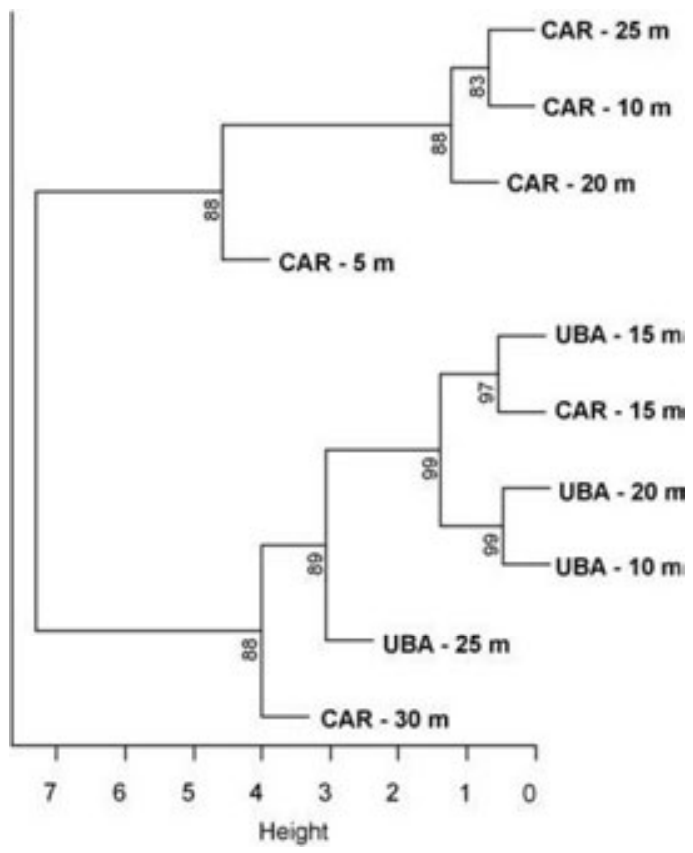

Fig. 1. Cluster analysis of the gastropod species' diversity utilized by the hermit crab Loxopagurus loxochelis (Diogenidae) in different depths (from 5 to $30 \mathrm{~m}$ ) and in two areas in São Paulo, Brazil. Values near groups are AU values (approximate unbiased bootstrap). CAR $=$ Caraguatatuba bay and UBA = Ubatuba bay

PCA axis 1 (90\% of variance explained), which was related to the chela width and the cephalothoracic shield length and width (Fig. 4), indicates differences between the sexes: the females of L. loxochelis were smaller than the males, irrespective of the shell utilized (Fig. 4). Axis 2 shows a tendency on the part of lighter females with larger cephalothoracic shields to occupy more $B$. gradatum than the other two gastropods and it can also be noted that small males are not found in S. haemastoma shells (Fig. 4). ANOSIM indicates that L. loxochelis male and female characteristics are significantly statistically different $(\mathrm{r}=0.20 ; \mathrm{p}<0.0001)$, but differences between the gastropod species' are not $(\mathrm{r}=0.054$; $\mathrm{p}=$ $0.006)$.

When occupation was analyzed, based on hermit size-class at Caraguatatuba, it was noticed that the animals in the smaller classes $(2.0 \vdash 4.4 \mathrm{~mm})$ occupied the $O$. urceu shells more frequently, and that, in the intermediate classes $(4.4+6.8 \mathrm{~mm})$, there was more frequent occupation of $B$. gradatum. In the final classes $(6.8+8.0 \mathrm{~mm})$, more diverse shell occupation was seen, and no hermit crabs were found occupying B. gradatum (Fig. 5). Juveniles (CSL $<4.0 \mathrm{~mm}$ ) used nine species of gastropod shells, $O$. urceus being the predominant one. At Ubatuba, O. urceus species were the most used by all size classes, except by the classes $6.8-7.4 \mathrm{~mm}$, the individuals of which occupied only B. gradatum (Fig. 6). Only in the intermediate classes $(4.4+6.8 \mathrm{~mm})$ did individuals of L. loxochelis use shells different from the two most frequently occupied ones. Juveniles used $O$. urceus shells almost exclusively ( $85.7 \%$ of juveniles).

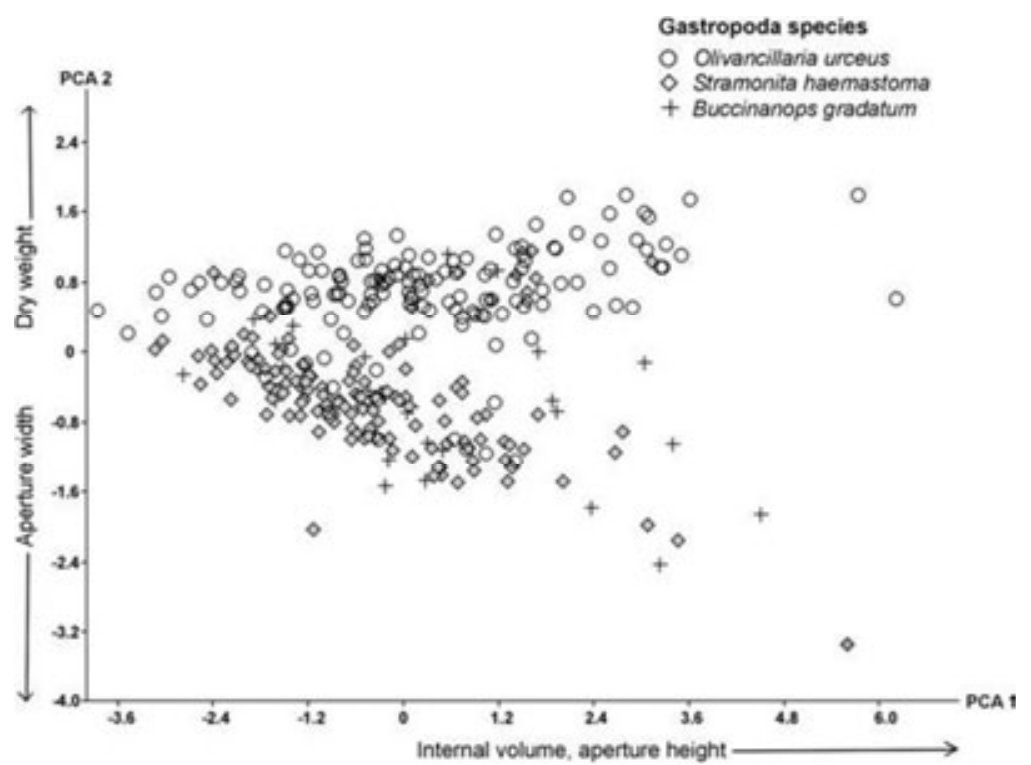

Fig. 2. Principal component analysis (PCA) of the gastropod shell's attributes occupied by the hermit crab Loxopagurus loxochelis (Diogenidae). The two attributes with larger scores of each PCA axis are shown next to the axes, and the setae indicate the direction of the increase. These two axes explained $90 \%$ of the total variance. 


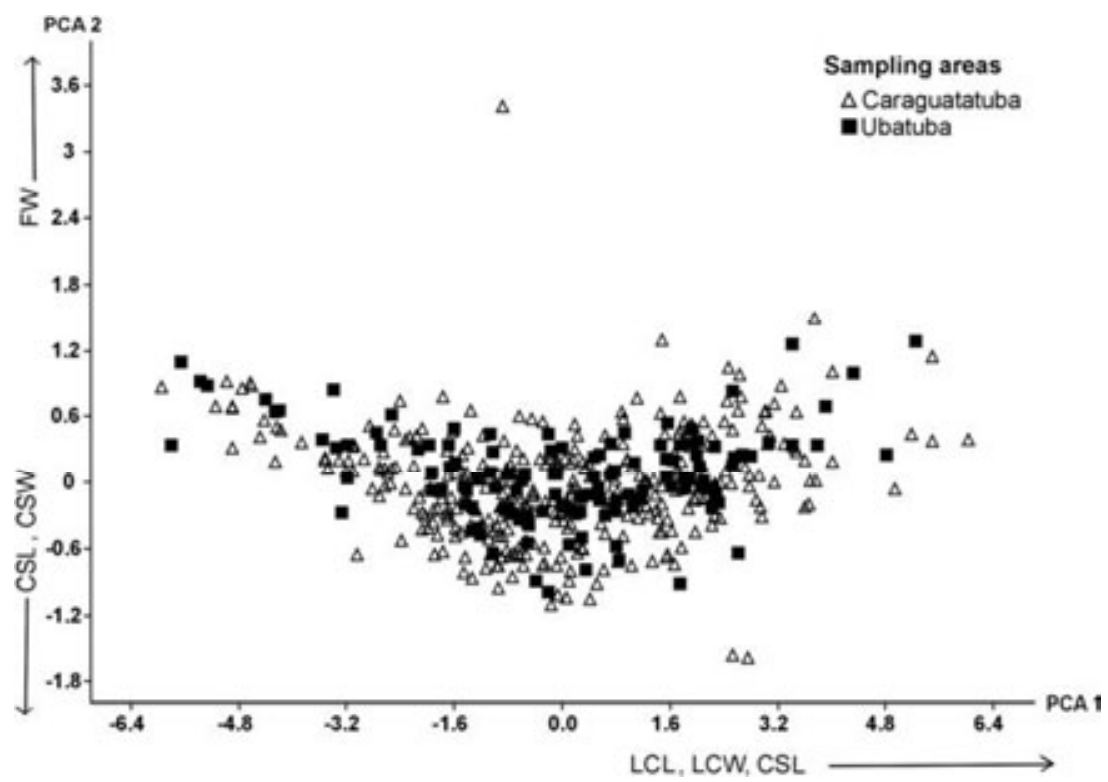

Fig. 3. Principal component analysis (PCA) of the hermit crab Loxopagurus loxochelis's (Diogenidae) attributes in two sampling areas in São Paulo, Brazil. The three attributes with larger scores of each PCA axis are shown next to the axes, and the setae indicate the direction of the increase. LCL $=$ left chela length; LCW $=$ left chela width; $\mathrm{CSL}=$ cephalothoracic shield length; $\mathrm{CSW}=$ cephalothoracic shield width. These two axes explained $95 \%$ of the total variance.

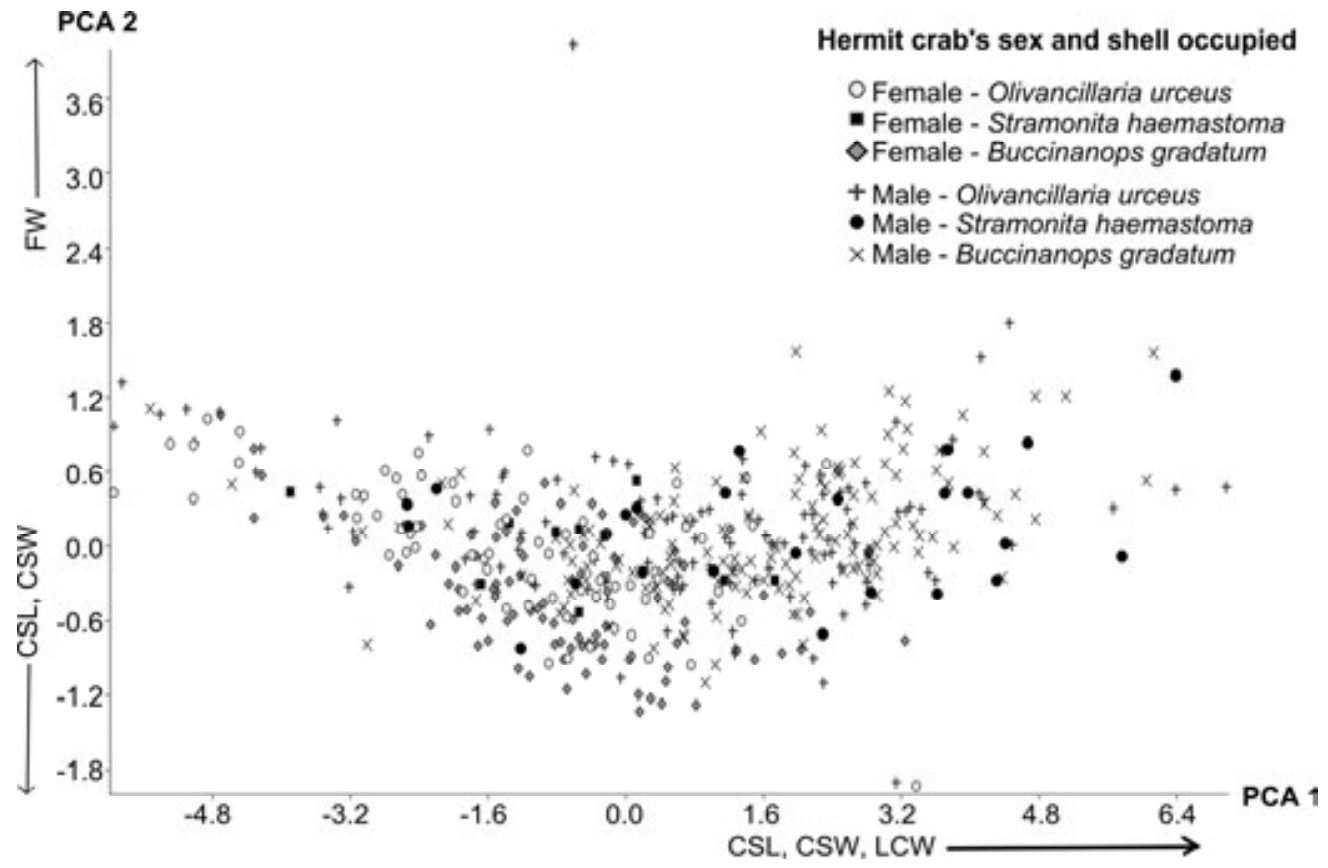

Fig. 4. Principal component analysis (PCA) of the hermit crab Loxopagurus loxochelis's (Diogenidae) attributes in two sampling areas in São Paulo, Brazil. The three attributes with larger scores of each PCA axis are shown next to the axes, and the setae indicate the direction of the increase. LCL $=$ left chela length; LCW $=$ left chela width $; \mathrm{CSL}=$ cephalothoracic shield length $\mathrm{CSW}=$ cephalothoracic shield width. These two axes explained $95 \%$ of the total variance. 


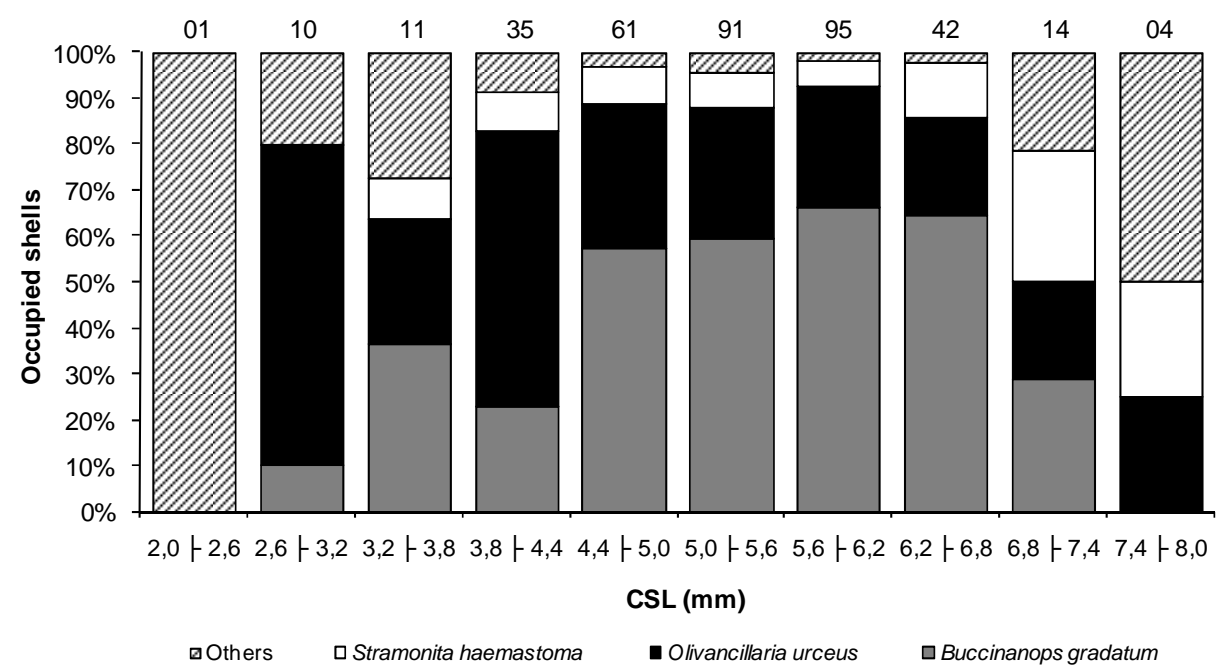

Fig. 5. Pattern of the gastropods' shells' occupation by Loxopagurus loxochelis in relation to the size class of the hermit crabs (CSL = cephalothoracic shield length); the number on the bars indicates the amount of individuals in each class. Animals sampled in Caraguatatuba, São Paulo, during July 2002 to June 2003.

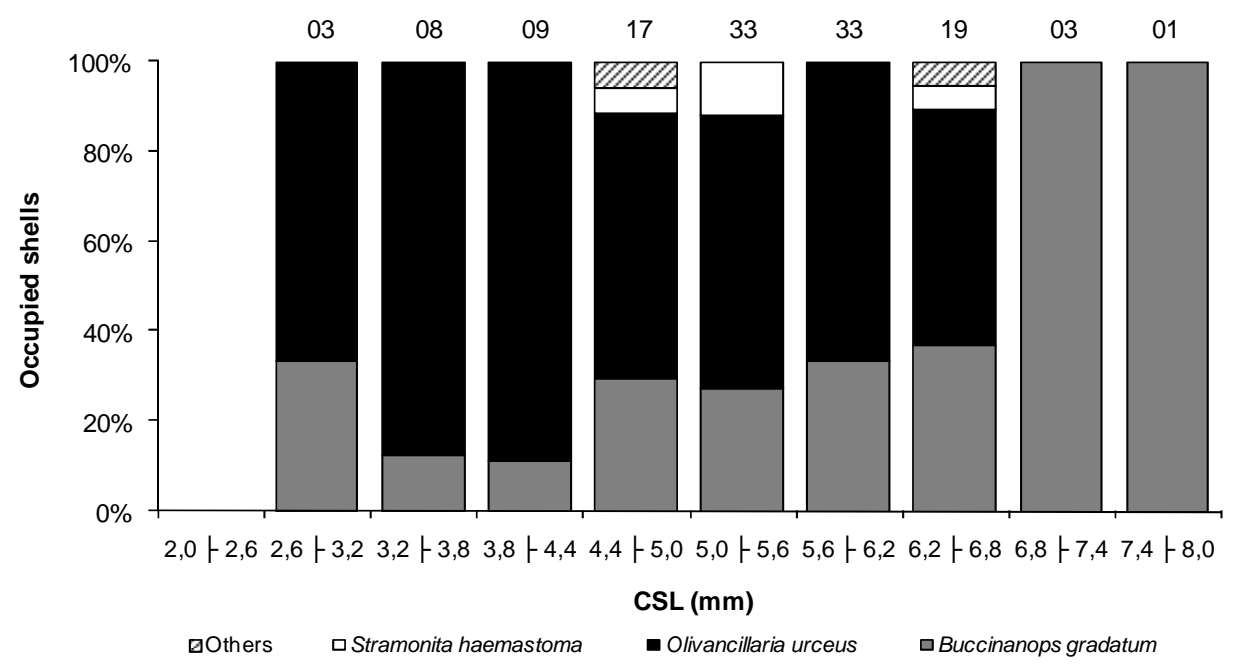

Fig. 6. Pattern of the gastropods' shells' occupation by Loxopagurus loxochelis in relation to the class of size of the hermit crabs (CSL = cephalothoracic shield length); the number on the bars indicates the amount of individuals in each class. Animals sampled in Ubatuba, São Paulo, during July 2002 to June 2003.

The regression tree successfully explained the relationship between the hermit crab's characteristics and the internal volume of the inhabited shell, accounting for $77 \%$ of the total variance (total of 325 ind.). The first split, separating the juveniles and the small adults - with a shield width smaller than 5.45 mm (193 ind.) - from the larger adults (132 ind.), explained $43 \%$ of the variance (Fig. 7). Juveniles and small adults occupied shells of up to an average 2.3 $\mathrm{mm}^{3}$, depending on their chela length and fresh weight. Large adults with shield length $>7 \mathrm{~mm}$ were rare (9 ind.), and represented only $2.7 \%$ of the total. These individuals occupied shells of from 6.0 to 8.4 $\mathrm{mm}^{3}$. Those individuals weighing more than $4 \mathrm{~g}$ inhabited the shells of the largest volume (mean of 8.4 $\mathrm{mm}^{3}$ ) (Fig. 7). 


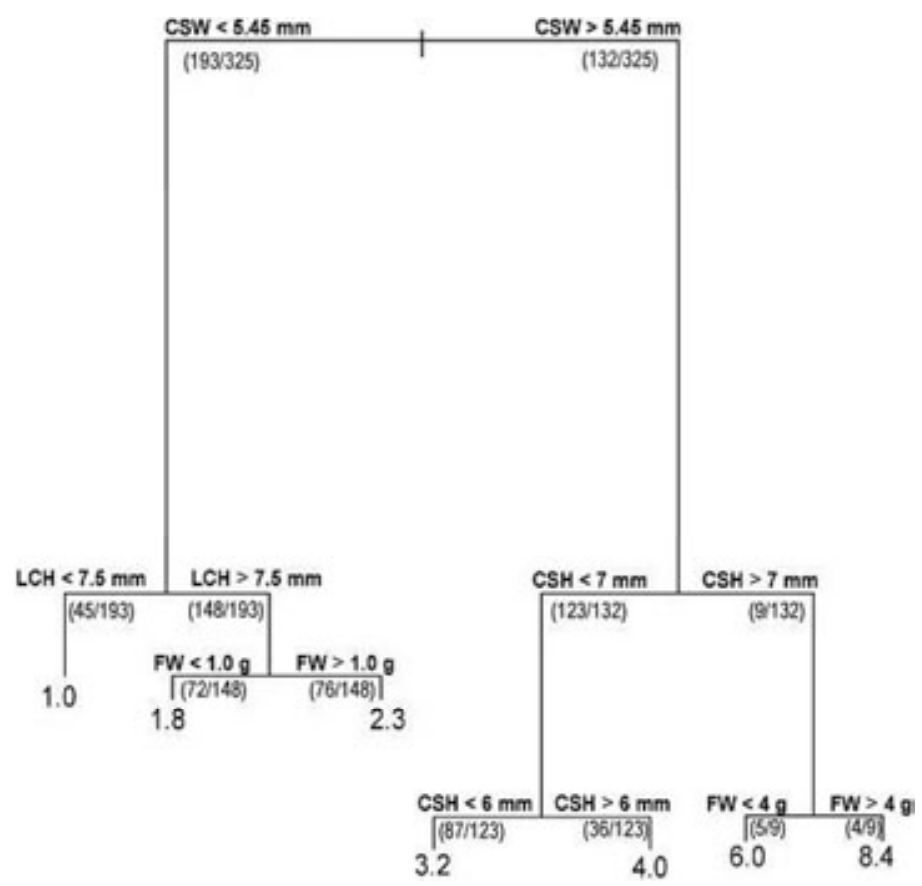

Fig. 7. Relationship between the hermit crab's attributes and the gastropod shell's internal volume $\left(\mathrm{mm}^{3}\right)$ accessed through a regression tree model. Numbers in the lowest portions of the tree (leaves) indicate the expected mean internal volume $\left(\mathrm{mm}^{3}\right)$ of the shell given the hermit crab attributes indicated in each split, out of the total. The numbers in parenthesis show the number of individuals satisfying the conditions of each split. Vertical lines are proportional to the total amount of the variance explained by each split. $\mathrm{CSW}=$ cephalothoracic shield width; $\mathrm{CSL}=$ cephalothoracic shield length; $\mathrm{LCL}=$ left chela length; FW = fresh weight.

\section{Discussion}

The two populations studied here differed with respect to the diversity of the gastropod shells they occupied in two close areas. These population profiles exhibited by Loxopagurus loxochelis evidence the importance of the adaptive mechanisms of establishment both in different and in close areas.

The differences in the patterns of shell occupancy between populations of the same species in different areas can be related to the diversity of the gastropod community in each respective area (MANTELATTO et al., 2010). However, it is worth mentioning that an overlap between areas was observed in the present study; Fig. 1 demonstrates that in Caraguatatuba's 15 and 30m depths there was a grouping with transects from Ubatuba, which demonstrates that part of the gastropod diversity overlaps, which would be responsible for some of the similarity in the shell occupation of L. loxochelis in the two areas.

Hermit crabs do not necessarily occupy the shells of all existent gastropod species in a given area. Martinelli and Mantelatto (1999), for example, recorded 16 different shell species in Ubatuba bay, and only six occupied by $L$. loxochelis. Olivancillaria urceus and $B$. gradatum are the most abundant gastropods in the Ubatuba and Caraguatatuba regions, respectively. Shells of $O$. urceus are heavier, with a high dry weight, and have a smaller opening width than the B. gradatum, as shown in Fig. 2. This characteristic may explain its more intense use in Ubatuba, since this area is more exposed to the ocean than is Caraguatatuba bay, more protected from the forces of the open sea (PIRES-VANIN et al., 1993), due to the presence of São Sebastião Island.

Different populations of the same species may differ greatly in their pattern of shell occupancy as a result of the physical and biological properties of the environment, such as wave strength and habitat heterogeneity (DOMINCIANO et al., 2009) and their indirect effects on shell quality and abundance (SCULLY, 1979). Differences in the shell occupancy patterns between populations of the same species inhabiting environments with different characteristics are very common amongst hermit crabs, and have been widely documented (LEITE et al., 1998; BOTELHO; COSTA, 2000; GARCIA; 
MANTELATTO, 2000; MANTELATTO et al., 2007; DOMINCIANO et al., 2009; MANTELATTO et al., 2010). It is important to highlight that both populations have similar physical characteristics, as shown in Fig. 3, which reinforces the idea that other factors, such as environmental pressure or competition with others, play a part in shell selection even though the individuals in the two areas show no differences in their sizes.

The diversity of the hermit species of a given locality is also related to the latitudinal distribution of the gastropod shells, as well as the distribution of other hermit species that may compete for the available shells (MANTELATTO; GARCIA, 2000). Regarding L. loxochelis, other hermit crab species occur in the study areas and a sharing of resources with respect to the available shells seems to exist between them. In Ubatuba, there are two other common hermit crab species [Dardanus insignis (Saussure, 1858) and Petrochirus diogenes (Linnaeus, 1758)] that are similar in size to L. loxochelis, but their patterns of shell occupancy are different: $D$. insignis occupies $25 \%$ of B. gradatum and $28 \%$ of $O$. urceus, while $P$. diogenes rarely occupies the shells preferred by $L$. loxochelis (1\% in B. gradatum and $2 \%$ in $O$. urceus) (BERTINI; FRANSOZO, 2000). In Caraguatatuba, L. loxochelis coexists with Isocheles sawayai (Forest \& Saint Laurent, 1968) and Pagurus exilis (Benedict, 1892) (FANTUCCI et al., 2008; TEROSSI et al., 2006, respectively). The former uses mainly S. haemastoma (B. gradatum $=5 \%$ and $O$. urceus $=5 \%)$ and it is found in shallow waters $(5 \mathrm{~m}$ deep) (FANTUCCI et al., 2008), where L. loxochelis occupies the highest diversity of shell types. In relation to $P$. exilis, there is a similarity with $L$. loxochelis in terms of size and distribution (MEIRELES et al., 2006) and, in Caraguatatuba, $P$. exilis uses the shells of 19 gastropod species, 11 of which are also used by $L$. loxochelis, but it shows a marked preference for B. gradatum (82\%) (TEROSSI et al., 2006).

We cannot, on the basis of these data, dismiss the hypothesis of interspecific competition for the shells, at least at some moment during the life cycle of the coexistent species. This prediction is supported by previous shell availability studies, in which Martinelli and Mantelatto (1999) detected that O. urceus is the most available gastropod shell at Ubatuba, and recently, working in different areas of the São Paulo State littoral, confirmed that $O$. urceus and $B$. gradatum, are, respectively, the most available gastropod species in both the regions studied Caraguatatuba and Ubatuba. The stocks of these resources permit some of the overlapping occupation verified in these species (L. loxochelis and $P$. exilis) in the region.
Intraspecific differences in shell selection also take place among hermit crabs, mainly related to reproduction. Light shells with large internal volume are thought to favor ovigerous females, as shell size influences the number of eggs a female can bear. Heavy shells, on the other hand, favor males by offering increased protection from predators during the competition for females (GHERARDI, 1991). Also, when fighting other males for access to a female, males with a larger shell may have an advantage over those in smaller shells (SATO, SENO; 2006). Examples of intraspecific differences have been documented for Pagurus maclaughlinae García Gómez, 1982 (TUNBERG et al., 1994); L. loxochelis (MARTINELLI; MANTELATTO, 1999; BIAGI et al., 2006); Pagurus brevidactylus (Stimpson, 1859) (MANTELATTO; MEIRELES, 2004); Calcinus tibicen (Herbst, 1791) (GARCIA; MANTELATTO, 2000), and Clibanarius vittatus (Bosc, 1802) (MANTELATTO et al., 2010). In our study, males tended to occupy heavier and larger shells than females (Fig. 4). Olivancillaria urceus shells are heavy and present an oval opening, thus being more adequate for males (MARTINELLI; MANTELATTO, 1999). The Buccinanops gradatum fusiform shell, the opening of which is wider and consequently has a greater internal volume, is more favorable to females during the egg production period (TORATI; MANTELATTO, 2008). Nonetheless, no intraspecific differences regarding the shell type used were observed in the present study such as those verified for L. loxochelis studied in south Brazil (AYRES-PERES et al., 2008). The same trend was observed in Cestopagurus timidus (Roux, 1830) by Pessani and Premoli (1993) and in $P$. exilis by Terossi et al. (2006). Interestingly, the differences in shell occupancy between the sexes of $C$. tibicen observed in nature (GARCIA; MANTELATTO, 2000; MANTELATTO; GARCIA, 2000) were not replicated under laboratory conditions (GARCIA; MANTELATTO, 2001), reinforcing the importance of the role of environmental conditions in shaping the hermit crab's shell preference.

According to Garcia and Mantelatto (2000), a sharing of shell resources among individuals probably occurs due to the scarcity of empty shells. The absence of inter sexual variation in the shell occupation pattern in populations of $L$. loxochelis may reflect the abundance and the availability of the most frequently occupied gastropod species' shells in those regions, which thus avoid competition between the sexes, since there are "adequate" shells available for the majority of individuals.

Loxopagurus loxochelis most frequently occupied the shells of $B$. gradatum and $O$. urceus. However, medium-sized individuals were found to occupy a larger diversity of shells than the smaller 
ones. Usually, the opposite occurs: the smaller individuals occupying the largest diversity of shells (REESE, 1969; MARTINELLI; MANTELATTO, 1999; GARCIA; MANTELATTO, 2000; MANTELATTO; GARCIA， 2000; MEIRELES; MANTELATTO, 2005), probably because it is easier for them to fit into a variety of shell shapes and sizes (VANCE, 1972a). Terossi et al. (2006) and Fantucci et al. (2008) also reported a higher diversity among medium-sized individuals. Our results reflect the availability of the most frequently occupied shells in all the hermit crabs' size classes.

The regression tree (Fig. 7) - a method that allows the utilization of various quantitative variables at the same time - revealed a close association between the hermit crab's variables and the internal volume of shells, which seems to be the most important determining factor in their occupation by L. Loxochelis both in Caraguatatuba and Ubatuba. Different studies identify different characteristics as, for example, the shell opening. In $C$. tibicen and $C$. vittatus, there was a positive relationship between shell weight and the hermit's weight (GARCIA; MANTELATTO, 2000; MANTELATTO et al., 2010). It has been demonstrated that the shell's internal volume is also another important attribute: in Pagurus pollicaris Say 1817 , the shell preference is determined by the shell's weight and volume and, in the laboratory, the latter attribute was identified as the most important (CONOVER, 1978); more recently, the importance of the shell's volume in P. exilis and I. sawayai has also been highlighted (TEROSSI et al., 2006; FANTUCCI et al., 2008, respectively); Biagi et al. (2006) observed that the relationship between the shell's aperture and its weight was the one that best reflected the shell's association with L. loxochelis in two separated regions in Argentina and Brazil; the same was observed by Ayres-Peres et al. (2008) when evaluating a population of the same species from south Brazil and Carranza et al. (2008) in a study with a population of $L$. loxochelis in Uruguay discovered that the closest relationship was between shell weight and left propodus length.

In the present study it was observed that $L$. loxochelis occupied preferably shells of B. gradatum and $O$. urceus in both the study areas, although in Caraguatatuba the hermit crabs used mainly $B$. gradatum and then $O$. urceus, in Ubatuba the pattern was the other way round $(O$. urceus was the most frequently used, followed by $B$. gradatum). The differences between the regions are probably related to the characteristics of each area, as well as to the availability of local shells, reflecting an adjustment of L. loxochelis to the resources of the environment. We conclude that the relationship between the morphometry of an individual hermit crab and its shell is not straightforward and cannot be explained just on the basis of direct correlations between the body's and the shell's characteristics. Actually, shell morphometry and availability are important determinants, as well as the environmental conditions and inter and intraspecific competition. All these factors interact and seem to be taken into consideration by the hermit crabs when choosing a shell, resulting in the diversified pattern of shell occupancy shown here and elsewhere. The outcome of the present study should be to encourage future comparative analysis of the aspects that guide the hermit crabs' use of shells in different areas.

\section{ACKNOWLEDGMENTS}

This study was part of a Master's degree by LAP and was supported by a CAPES fellowship. Support for field activities of this project was provided by FAPESP - Programa Biota (Proc. 98/07090-3) under Dr. Adilson Fransozo's coordination, the use of whose logistical support and facilities during field work we gratefully acknowledge. Part of this study was supported by funding from $\mathrm{CNPq}$ (grants $471794 / 2006-6 ; 473050 / 2007-2 ; 301350 / 2007-5)$ to FLM. Special thanks are due to all the members of NEBECC (UNESP - Botucatu) and of the Laboratory of Bioecology and Crustacean Systematics (LBSC/FFCLRP/USP) for their help during the field and laboratory work. The support of the Postgraduate Program in Comparative Biology of FFCLRP/USP and of the Centro de Biologia Marinha (CEBIMar/USP) during the collections is also acknowledged. Special thanks go also to Dr. Marcelo Scelzo (Universidad de Mar del Plata), Dr. Roberto Shimizu (IB/USP) and an anonymous reviewer for their suggestions and contributions toward the improvement of this paper, and to Julia Hetem for the English revision. All the experiments conducted during this study complied with the current applicable state and federal laws of Brazil.

\section{REFERENCES}

AYRES-PERES, L.; MANTELATTO, F. L. Análise comparativa da estrutura populacional do ermitão endêmico do Atlântico Ocidental Loxopagurus loxochelis (Decapoda, Anomura) em duas regiões do Estado de São Paulo, Brasil. Iheringia, Sér. Zool., v. 98, n. 1, p. 28-35, 2008

AYRES-PERES, L.; MANTELATTO, F. L. Patterns of distribution of the hermit crab Loxopagurus loxochelis (Moreira, 1901) (Decapoda, Diogenidae) in two coastal areas of southern Brazil. Rev. Biol. Mar. Oceanogr., v. 43, n. 2, p. 399-411, 2008a.

AYRES-PERES, L.; MANTELATTO, F. L. Epibiont occurrence on gastropod shells used by the hermit crab Loxopagurus loxochelis (Anomura: Diogenidae) on the northern coast of São Paulo, Brazil. Zoologia, v. 27, n. 2, p. $222-227,2010$. 
AYRES-PERES, L.; SOKOLOWICZ, C. C.; KOTZIAN, C. B.; RIEGER, P. J.; SANTOS, S. Ocupação de conchas de gastrópodes por ermitões (Decapoda, Anomura) no litoral de Rio Grande, Rio Grande do Sul, Brasil. Iheringia, Sér. Zool., v. 98, n. 2, p. 218-24, 2008.

BARNES, D. K. A. Ecology of tropical hermit crabs at Quirimba Island, Mozambique: shell characteristics and utilization. Mar. Ecol. Prog. Ser., v. 183, p. 241-251, 1999.

BERTINI, G.; FRANSOZO, A. Patterns of shell utilization in Petrochirus diogenes (Decapoda, Anomura, Diogenidae) in the Ubatuba region, São Paulo, Brazil. J. Crust. Biol., v. 20, n. 3 , p. $468-473,2000$.

BERTNESS, M. D. The influence of shell-type on hermit crab growth rate and clutch size. Crustaceana, v. 40, n. 2, p. 197-205, 1981.

BERTNESS, M. D. Shell utilization, predation pressure, and thermal stress in Panamanian hermit crabs: an interoceanic comparison. J. exp. mar. Biol. Ecol., v. 64, n. 2, p. $159-187,1982$

BIAGI, R.; MEIRELES, A. L.; SCELZO, M. A.; MANTELATTO, F. L. Comparative study of shell choice by the southern endemic hermit crab Loxopagurus loxochelis from Brazil and Argentina. Rev. Chil. Hist. Nat., v. 79, n. 4, p. 481-487, 2006

BOLLAY, M. Distribution and utilization of gastropod shells by the hermit crabs Pagurus samuelis, Pagurus granosimanus and Pagurus hirsutiusculus at Pacific Grove, California. Veliger, v. 6 (suppl.), p. 71-76, 1964

BOTELHO, Z. B.; COSTA, A. C. Shell occupancy of the intertidal hermit crab Clibanarius erythropus (Decapoda, Diogenidae) on São Miguel (Azores). Hydrobiologia, v. 440, p. 111-117, 2000.

CARRANZA, A.; SEGURA, A.; LOPEZ, J.; RUBIO, L. Shell use patterns of the hermit crab Loxopagurus loxochelis (Decapoda: Diogenidae) in Cerro Verde - La Coronilla (Rocha, Uruguay). Comun. Soc. Malacol. Urug., v. 9, n. 91, p. 139-145, 2008.

CHILDRESS, J. R. Behavioral ecology and fitness theory in a tropical hermit crab. Ecology, v. 53, n. 3, p. 960-964, 1972.

CONOVER, M. R. The importance of various shell characteristics to the shell - selection behavior on the hermit crabs. J. exp. mar. Biol. Ecol., v. 32, n. 2, p. 131142,1978 .

DEATH, G. Multivariate regression trees: a new technique for modelling species-environment relationships. Ecology, v. 83, n. 4, p. 1105-1117, 2002.

DEATH, G.; FABRICIUS, K. E. Classification and regression trees: A powerful yet simple technique for ecological data analysis. Ecology, v. 81, n. 11, p. 31783192, 2000.

DOMINCIANO, L. C. C.; SANT'ANNA, B. S.; TURRA, A. Are the preference and selection patterns of hermit crabs for gastropod shells species or site-specific? J. exp. Mar. Biol. Ecol., v. 378, n. 1, p. 15-21, 2009.

ELWOOD, R. W.; MARKS, N.; DICK, J. T. A. Consequences of shell - species preferences for female reproductive success in the hermit crab Pagurus bernhardus. Mar. Biol., v. 123, n. 3, p. 431434, 1995.
FANTUCCI, M. Z.; BIAGI, R.; MANTELATTO, F. L. Shell occupation by the endemic western Atlantic hermit crab Isocheles sawayai (Diogenidae) from Caraguatatuba, Brazil. Braz. J. Biol., v. 68, n. 4, p. 859-867, 2008.

FOTHERINGHAM, N. Hermit crabs as a limiting resource (Decapoda, Paguridae). Crustaceana, v. 31, n. 2, p. 193199, 1976.

FOTHERINGHAM, N. Effects of shell stress on the growth of hermit crabs. J. exp. mar. Biol. Ecol., v. 23, n. 3, p. 299-305, 1976a.

GARCIA, R. B.; MANTELATTO, F. L. Variability of shell occupation by intertidal and infralittoral Calcinus tibicen (Anomura, Diogenidae) populations. Nauplius, v. 8, n. 1, p. 99-105, 2000.

GARCIA, R. B.; MANTELATTO, F. L. Shell selection by the tropical hermit crab Calcinus tibicen (Herbst, 1791) (Anomura, Diogenidae) from Southern Brazil. J. exp. mar. Biol. Ecol., v. 265, n. 1, p. 1-14, 2001.

GHERARDI, F. Relative growth, population structure, and shell utilization of the hermit crab Clibanarius erythropus in the Mediterranean. Oebalia, v. 17, p. 181 196, 1991.

GRANT, W. C.; ULMER, K. M. Shell selection and aggressive behavior in two sympatric species of hermit crabs. Biol. Bull., v. 146, n. 1, p. 32-43, 1974.

HAMMER, $\varnothing . ;$ HARPER, D. A. T.; RYAN, P. D. PAST: Paleontological Statistics Software Package for Education and Data Analysis. Palaeontologia Electronica $\quad 4(1): 9 \mathrm{pp} . \quad \mathrm{http} / / \mathrm{palaeo}-$ electronica.org/2001_1/past/issue1_01.htm, 2001.

HAZLETT, B. A. The behavioral ecology of hermit crabs. Ann. Rev. Ecol. Syst., v. 12, n. 1, p. 1-22, 1981.

KELLOGG, C. W. Gastropod shells: a potentially limiting resource for hermit crabs. J. exp. mar. Biol. Ecol., v. 22, n. 1, p. 101-111, 1976.

LEITE, F. P. P; TURRA, A; GANDOLFI, S. M. Hermit crabs (Crustacea: Decapoda: Anomura), gastropod shells and environment structure: their relationship in southeastern Brazil. J. Nat. Hist., v. 32, n. 10-11, p. 1599-1608, 1998.

MANTELATTO, F. L.; GARCIA, R. B. Shell utilization pattern of the hermit crab Calcinus tibicen (Diogenidae) from Southern Brazil. J. Crust. Biol., v. 20, n. 3, p. 460467, 2000.

MANTELATTO, F. L.; MEIRELES, A. L. The importance of shell occupation and shell availability in the hermit crab Pagurus brevidactylus (Stimpson, 1859) (Paguridae) population from the southern Atlantic. Bull. mar. Sci., v. 75, n. 1, p. 27-35, 2004.

MANTELATTO, F. L.; ALARCON, V. F.; GARCIA, R. B. Egg production strategies of the tropical hermit crab Paguristes tortugae from Brazil. J. Crust. Biol., v. 22, n. 2, p. 390-397, 2002.

MANTELATTO, F. L.; BIAGI, R.; MEIRELES, A. L; SCELZO, M. A. Shell preference of the hermit crab Pagurus exilis (Anomura: Paguridae) from Brazil and Argentina: a comparative study. Rev. Biol. Trop., v. 55, p. $153-161,2007$.

MANTELATTO, F. L.; FERNANDES-GÓES, L. C.; FANTUCCI, M. Z.; BIAGI, R.; PARDO, L. M.; GÓES, J. M. A comparative study of population traits between two South American populations of the striped-legged hermit crab Clibanarius vittatus. Acta Oecol., v. 36, n. 1, p. 10-15, 2010. 
MARKHAM, J. Notes on the growth patterns and shell utilization of the hermit crab Pagurus bernhardus (L.). Ophelia, v. 5, p. 189-205, 1968.

MARTINELLI, J. M.; MANTELATTO, F. L. Occurrence of exobionts in gastropod shells occupied by the hermit crab Loxopagurus loxochelis (Anomura: Diogenidae) in Ubatuba Bay (SP) Brazil. In: Anais do IV Simpósio de Ecossistemas Brasileiros, v. 2, n. 104. Publicações ACIESP, São Paulo, p. 221-226, 1998.

MARTINELLI, J. M.; MANTELATTO, F. L. Shell utilization by the hermit crab Loxopagurus loxochelis (Diogenidae) in Ubatuba Bay, Brazil. In: SCHRAM, F. R. \& VANPEL KLEIN, J. R. (eds.). Crust. Biodiv. Crisis, v. 1, p. 719-731, 1999.

MEIRELES, A. L.; MANTELATTO, F. L. Shell use by the Pagurus brevidactylus (Anomura, Paguridae): a comparison between laboratory and field conditions. Acta Zool. Sin., v. 51, n. 5, p. 813-820, 2005.

MEIRELES, A. L.; TEROSSI, M.; BIAGI, R.; MANTELATTO, F. L. Spatial and seasonal distribution of the hermit crab Pagurus exilis (Benedict, 1892) (Decapoda: Paguridae) in the southwestern coast of Brazil. Rev. Biol. Mar. Oceanogr., v. 41, n. 1, p. 87-95 2006.

MELO, G. A. S. Manual de identificação dos Crustacea Decapoda do litoral brasileiro: Anomura, Thalassinidea, Palinuridea, Astacidea. Plêiade, São Paulo, 551 p, 1999.

MITCHELL, K. A. Shell selection in the hermit crab Pagurus bernhardus. Mar. Biol., v. 35, n. 4, p. 335-346, 1976.

OHMORI, H.; WADA, S.; GOSHIMA, S.; NAKAO, S. Effect of body size and shell avaibality on the shell utilization pattern of the hermit crab Pagurus filholi (Anomura: Paguridae). Crust. Res., v. 24, p. 85-92, 1995.

PESSANI, D.; PREMOLI, C. Some aspects of the biology of Cestopagurus timidus (Crustacea, Paguridae) in relation to the occupied shell. Boll. Zool., v. 60, n. 2, p. 199-205, 1993.

PRASAD, A. M.; IVERSON, L. R.; LIAW, A. Newer classification and regression tree techniques: Bagging and random forests for ecological prediction. Ecosystems, v. 9, p. 181-199, 2006.

PIRES-VANIN, A. M. S.; ROSSI-WONGTSCHOWSKI, C. L.; AIDAAR, E.; MESQUITA, H.; SOARES, L. S. H.; KATSURAGAWA, M.; MATSUURA, Y. Estrutura e função do ecossistema de plataforma continental do Atlântico Sul brasileiro: síntese dos resultados. Publ. esp. Inst. Oceanogr., v. 10, p. 217-231, 1993.

PROVENZANO Jr., A. J. Notes on Bermuda hermit crabs (Crustacea: Anomura). Bull. Mar. Sci. Gulf Caribb., v. 10, p. 117-124, 1960.
R Development Core Team. R: A language and environment for statistical computing. R Foundation for Statistical Computing, Vienna, Austria. ISBN 3-900051-07-0, URL http://www.R-project.org, 2010.

REESE, E. Behavioral adaptation of intertidal hermit crabs. Am. Zool., v. 9, n. 2, p. 343-355, 1969.

RIOS, E. C. Seashells of Brazil. Rio Grande do Sul. Fundação Universidade de Rio Grande, Instituto Acqua, Museu Oceanográfico de Rio Grande, Universidade de Rio Grande. 2ed. 368 p. + 113pl., 1994.

SATO, Y.; SENO, H. A mathematical consideration for the optimal shell change of hermit crab. J. Theor. Biol., v. 240, p. 14-23, 2006.

SCULLY, E. P. The effects of gastropod shell availability and habitat characteristics on shell utilization by the intertidal hermit crab Pagurus longicarpus Say. J. exp. mar. Biol. Ecol., v. 37, n. 2, p. 139-152, 1979.

SPIGHT, T. M. Availability and use of shells by intertidal hermit crabs. Biol. Bull., v. 152, n. 1, p. 120-133, 1977.

SUZUKI, R.; SHIMODAIRA, H. PVCLUST v 1.2-0. R package version 3.1-34. URL http://www.R-project.org, 2006.

TEROSSI, M.; ESPÓSITO, D. L. A.; MEIRELES, A. L.; BIAGI, R.; MANTELATTO, F. L. Pattern of shell occupation by the hermit crab Pagurus exilis (Anomura, Paguridae) in southern Atlantic region. J. Nat. Hist., v. 40, n. 1-2, p. 77-87, 2006.

TORATI, L. S.; MANTELATTO F. L. Uncommon mechanism of egg incubation in the endemic Southern hermit crab Loxopagurus loxochelis: how is this phenomenon related to egg production? Acta Zool., v. 89, n. 1, p.79-85, 2008.

THERNEAU, T. M.; ATKINSON, B. RPART: Recursive Partitioning. Report by B. Ripley. R package version 3.1-34. URL http://www.R-project.org, 2010.

TUNBERG, B. G.; NELSON, W. G.; SMITH, G. Population ecology of Pagurus maclaughlinae Garcia-Gomes (Decapoda: Anomura: Paguridae) in the Indian River Lagoon, Florida. J. Crust. Biol., v. 14, n. 4, p. 686-699, 1994.

VANCE, R. R. The role of shell adequacy in behavior interactions in hermit crabs. Ecology, v. 53, n. 6, p. 1075-1083, 1972.

VANCE, R. R. Competition and mechanisms of coexistence in three sympatric species of intertidal hermit crabs. Ecology, v. 53, n. 6, p.1062-1074, 1972a. 